\title{
Commercialization of Green Corn-Based Silage Production for Dairy in Cagayan Valley: Profitability and Viability Assessment
}

\author{
Diosdado C. Cañete ${ }^{1}$, Teresa S. Alvarez, \\ ${ }^{1}$ Agribusiness and Agricultural Economics, College of Agriculture, Isabela State University, Echague, Isabela, Philippines \\ ${ }^{2}$ Department of Accountancy, Isabela State University, Echague, Isabela, Philippines
}

Received January 4, 2021; Revised April 24, 2021; Accepted May 16, 2021

\section{Cite This Paper in the following Citation Styles}

(a): [1] Diosdado C. Cañete, Teresa S. Alvarez, "Commercialization of Green Corn-Based Silage Production for Dairy in Cagayan Valley: Profitability and Viability Assessment," Universal Journal of Agricultural Research, Vol. 9, No. 3, pp. 79 - 90, 2021. DOI: 10.13189/ujar.2021.090303.

(b): Diosdado C. Cañete, Teresa S. Alvarez (2021). Commercialization of Green Corn-Based Silage Production for Dairy in Cagayan Valley: Profitability and Viability Assessment. Universal Journal of Agricultural Research, 9(3), 79 90. DOI: 10.13189/ujar.2021.090303.

Copyright $(2021$ by authors, all rights reserved. Authors agree that this article remains permanently open access under the terms of the Creative Commons Attribution License 4.0 International License

\begin{abstract}
This study assessed the profitability and viability for the commercialization of green corn-based silage production for dairy in Cagayan Valley. Specifically, a.) Determine the cost and return analysis of producing corn green silage; b.) Compare the cost and return for the different opportunities of dairy farmers in engaging silage production; and c.) Assess the profitability and viability of dairy as fed with green corn silage. Malaya Development Cooperative (MDC) has operated with Dairy Buffalo while, San Agustin Dairy Cooperative (SADACO) is engaged in Dairy Carabao production. There were various packages of technologies introduced for adoption like green corn production, green corn silage. Option 3 (planting corn, processed as silage, and sold as silage) has contributed with the highest net return of Php145,565.00 annually while, option 4 (plant corn, process it as green corn silage, feed it as silage to 3 heads dairy Carabao) with net income of Php71,184.63 annually. For viability, option 3 has showed with the best viability results, the lowest payback period of 0.82 year; higher net present value of Php459,634.71 and higher Internal rate of return with $124.21 \%$.
\end{abstract}

Keywords Dairy Production, Profitability, Viability, Green Corn Silage

\section{Introduction}

Acosta and Victorio [12], state that the Philippines imports, most of its milk requirements from leading dairy producing countries despite of the availability of vast tract of lands suitable for dairy production. According to Bureau of Agriculture [8], the Cagayan Valley is a major producer of rice and corn. Hence, feed resources (to include green corn as forage or silage, rice straw, corn stover) are expected abundant for ruminants. Aquino [13], on his study, found that despite the vast rice and corn areas in the valley, dairy farmers' still face scarcity problem of quality feed resources for dairy animals especially during dry season to sustain or boost dairy milk production. It could be premised on the seasonality of producing rice and corn. In addition, the supply of quality and sustainable forage is very low during dry season.

Aquino [13], reported that a year - round access to quality feed and roughage determines the competitiveness of the dairy sector. Forages and roughages are the backbone of the dairy industry, largely because dairy cows are ruminants, making them highly dependent on forage for milk production. Hence, raisers of ruminants need to be proficient in the management of forages as in the management of their animals. Boehlie [1],on his findings, the development of a high-quality alternative feeding system in lieu of feeding forages during lean months 
therefore, will reduce the farmers' production costs and seasonal fluctuations in milk supply, thereby, improving operational profits.

Authors [12],8],[9], opined out that Corn silage is a high energy feed resource for ruminants. According to the studies conducted by [12], [13], being part forage and part grain, it has characteristics of both feed types and is a valuable component of dairy rations in regions where corn is grown. Gebremedhin [4] opined that in terms of nutrient content, corn silage is lower in crude protein $(\mathrm{CP})$ and higher in digestible energy (DE) than other forages. It also differs from other forages in that quality does not decline with advancing maturity. Ferraretto, et.al [2] based on their findings that this is because the increasing amount of grain in the crop offsets the decline in digestibility normally associated with structural tissue. Compared to many crops, corn is relatively easy to ensile.

Authors [2],[4],[8], agreed that farmers have to address the problems on how to improve the nutrition of farmers' dairy animals. During lean months, the major fodders available are rice straw or corn stover, together with ipil-ipil, kakawate and indigenous grasses like Carabao grass as opined by authors [3],[5]. As a minimum feed requirement, it is essential to provide a green fodder or legumes e.g. centrosema, ipil-ipil and the like as supplement to enhance rumen function for bovine animals as findings for the studies conducted [5],[6]. Therefore, one should develop summer fodder crops. For smallholder farmers with limited production capacity, procurement of enough feed specially during summer months to maintain good milk production has always been a problem according to PHILSAN [10]. Many are forced to feed rice straw, concentrate or silage just to keep their animals alive and are unable to benefit due to the higher prices paid for animal feed in the summer months.[3],[6],[14]. Hence the importance of the knowledge of producing affordable but high-quality silage that can be kept and fed during feed scarcity.

As opined by authors [11],[13],[15], Silage is considered the most convenient way to conserve forage crops. A forage crop needs $30 \%$ dry matter content to be ensiled successfully. Silage making has been practiced by the large ruminant sector, but the production method relies on the use of equipment and facilities by the large hold dairy farmers which are beyond the reach of smallholder farmers.

The improvement of feed supply for ruminants is very important not only during dry season (lean months) because this period is always associated with the decline in body weight and productivity of grazing dairy animals but also throughout the year. [3],[9]. Current nutrition research addresses this issue in order to develop a practical and consistent feeding scheme both for the backyard and commercial dairy livestock production enterprise. Forage production and silage making must be adapted in the farm for optimum production. This practical ration formulation is very simple and the needed feedstuff is locally available in the farm. If properly prepared, silage enriched with locally available materials such as kakawate, etc. could provide a year-round sustainable feed supply with low-cost quality nutrients for livestock as findings of the studies. [1],[8]. This may also reduce the daily labor input for cut and carry of silage and also the input cost in feeding supplementary concentrates.

In the dairy industry, year-round availability of quality feed resources has been a perennial problem that eventually affects milk production. Higher milk production is observed during wet season where quality forages are available as mentioned by [6], [10],[12]. However, their milk production is still below the expected level due to the quality of feeds fed. The increase or decrease of the milk production during wet and dry season is therefore obviously correlated with the availability and quality of feed resource. Usually, low rates of forage technology adoption by farmers are attributed to the following: inadequate farmers' understanding on the nutrient requirements of dairy animals, farmers' reluctance to accept new technology, inadequacy of extension services; non-participation to on-station of researchers; and dairy farmers' lack of access to viable planting materials.[6],[10].

Green corn silage production, has been proven to improve nutrition among dairy animals. [6],[15]. However, adoption of these products is low, more so, in producing them on commercial scale.

The strategies of addressing one of the pressing problems that discourages dairy farmers to venture into a large-scale dairy production which is the problem on the scarcity of quality feeds (silage), adoption and commercialization of quality feeds (silage) made from locally available resources such as kakawate, ipil-ipil and other locally available materials to increase its micro \& macro nutrients, not only during lean months, but year round.

Generally, the study assessed the profitability and viability for the commercialization of green corn-based silage production for dairy in Cagayan Valley.

Specifically, it aimed to: a.) determine the cost and return analysis of producing corn green silage; b.) compare the cost and return for the different opportunities of dairy farmers in engaging silage production; and c.) assess the profitability and viability of dairy as fed with green corn silage.

\section{Methods}

There were two groups of respondents of the study such as Malaya Development Cooperative (MDC) at Mallig, Isabela and San Augustin Dairy Cooperative (SADACO) who are engaged in dairy cattle and dairy Carabao respectively from 2017 to 2019 . 
Malaya Development Cooperative (MDC), a development cooperative assisted by the National Dairy Authority (NDA) and Philippine Carabao Center (PCC) located at Maligaya, Mallig, Isabela. At present, there are 448 members with approximately 100 heads of Holstein-Sahiwal provided by the NDA seven years ago. Average milk production is 2-4 liters per head/day and an average lactation period of 220 days. All members are rice-corn producers with an average irrigated landholding of 1.3 hectares.

San Agustin Dairy Cooperative (SADACO) is a dairy cooperative registered with Cooperatives Development Authority (DA) in 2012. Thirteen dairy associations in the whole municipality of San Agustin have been federated to form SADACO with 39 incorporators an initial capital of Php15,000.00. The Philippine Carabao Center (PCC) has initiated its establishment as a dairy cooperative. The cooperative was recipient of dairy Carabao/buffalos from PCC.

The data were gathered through semi-structured questionnaire, observation and calculated from the reports of the cooperatives and analyzed through cost and return for profitability, while capital budgeting analysis for viability assessment.

\section{Results and Discussion}

\section{Package of Technology}

The various packages of technologies (POTs) of dairy feed mix and supplements developed, showcased, and introduced for adoption and commercialization were assessed on its financial profitability and viability as independent or complementary business enterprises.

As an independent enterprise, the profitability and viability of the green corn silage enterprise were assessed.

As complementary enterprise, profitability and viability of producing green corn were processed as silage and fed to dairy animal and milk as it revenue.

A small-scale dairy farmer with farm lot (i.e. a family with 3 heads dairy Carabao or buffalo and a 1.5 hectares farm lot) has several options. These were:

Option 1 - Plant corn and sell it as grain (as usual practice)

Option 2 - Plant corn and sell it as green corn for silage

Option 3 - Plant corn, process it and sell it as silage

Option 4 - Plant corn, process it as green corn silage, feed it as silage to 3 heads dairy animals owned by the family. The revenue will be sales of milk produced.

Option 5 - Plant napier grass (pachong) and feed it ad libitum as forage to 3 heads dairy animals owned by the family. The revenue will be sales of milk produced.

\section{Profitability Analysis}

With the introduction of green corn silage, a traditional corn farmer was given three options such as:

Option 1 - Plant corn and sell it as grain (as usual practice)

Option 2 - Plant corn and sell it as green corn for silage

Option 3 - Plant corn, process it as green silage and sell it as silage

The profitability of each of these options are shown below:

\section{Option 1 - plant corn and sell it as grain (as usual practice)}

A hectare of land planted with corn with a yield of 6,000 kgs (or 120 cavans per hectare per cropping at a price of Php8.00/kg will have net profit of Php19,000.00. Since a cropping would entail 4 months, a corn farmer selling his crop as corn grain assuming no change in yield per hectare and selling price per $\mathrm{kg}$ will have a Php38,000.00 net revenue per annum. To break-even, the selling price must be Php4.83 per kg, or at the current price of Php $8.00 / \mathrm{kg}$ the corn farmer must produce $3,625 \mathrm{kgs}$ or 72.5 cavans of corn grain per hectare (Table 1).

\section{Option 2 - plant corn and sell it as green corn for silage}

If a market for green corn for silage exists, a corn farmer has now two options: sell his crop as corn grain (Option 1) or sell his corn crop as green corn for silage (Option 2).

Given the same corn land (Option 1), if the farmer will plant corn and sell it as green corn for silage the profitability as shown in Table 2 .

A hectare of land can be planted with 70,000 seeds and at a $5 \%$ mortality, a net survival seedling of 66,500 is expected. One corn plant at 65-80 days after planting will attain a weight of at least $1 \mathrm{~kg}$ per plant but for hybrid seeds it can attain up to $3-5 \mathrm{kgs}$ per plant. Assuming the least 5\% mortality and $1 \mathrm{~kg}$ weight per plant at 65-80 days after planting, and $\mathrm{Php} 1.00 / \mathrm{kg}$ buying price, a net revenue of Php31,500.00 is expected. Break-even price of Php 0.53 per $\mathrm{kg}$ and a breakeven quantity of $35,000 \mathrm{kgs}$ per hectare is expected. In the same piece of land, a corn farmer is expected to generate an annual revenue of at least Php63,000.00 if the farmer is only able to plant corn twice a year. Take note however, that green corn for silage is harvested 65-80 days after planting. It is therefore possible to harvest green corn 3-4 times per annum. If the farmer is able to plant three time a year, a net revenue of Php94,500.00 can be attained. 
Table 1. Cost and return analysis, corn production sold as grain (Option 1)

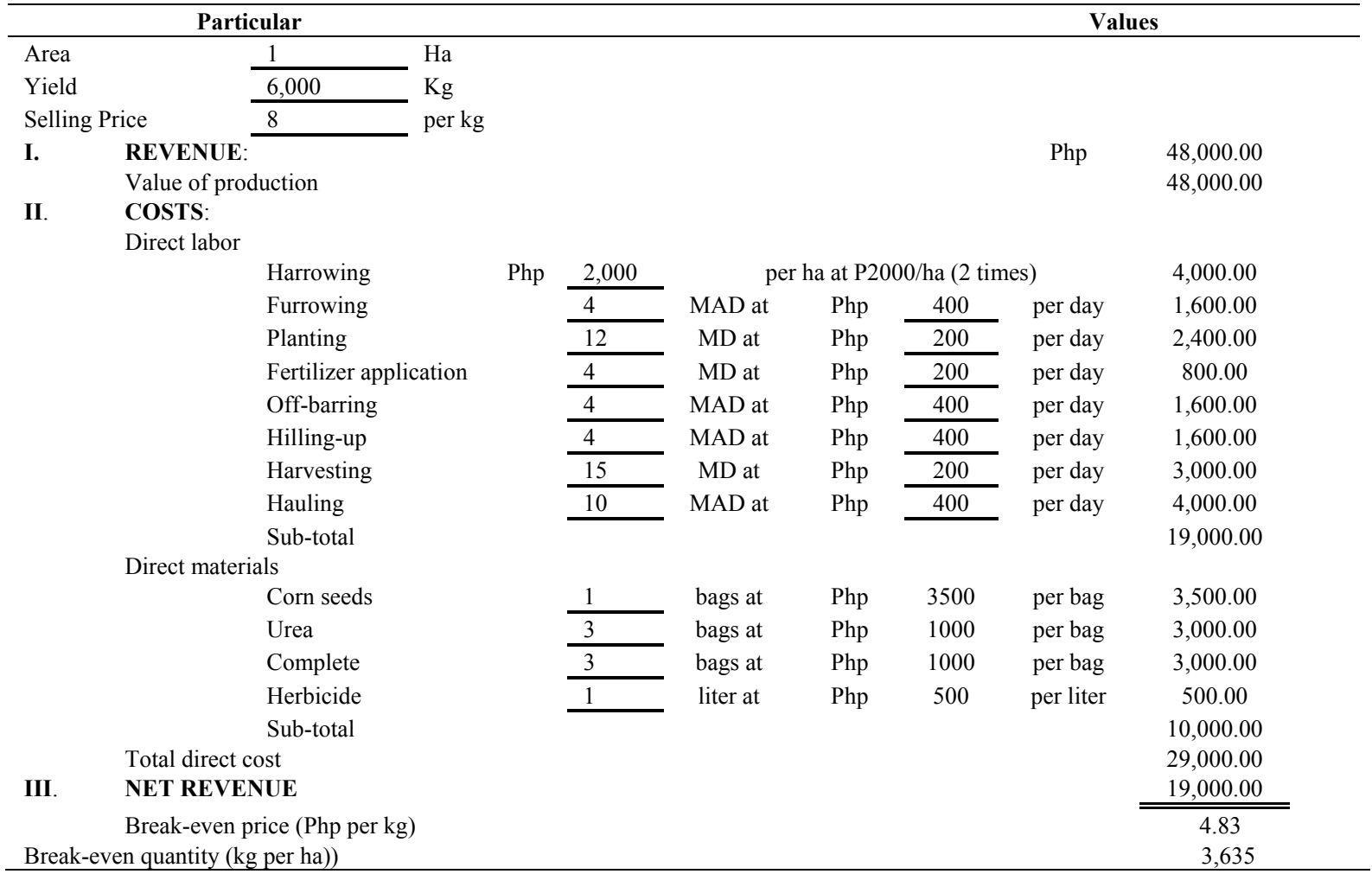

*MAD - man animal day

*MD - man day

Table 2. Cost and return analysis, green corn for silage (Option 2).

\begin{tabular}{|c|c|c|c|c|c|c|c|c|c|}
\hline \multicolumn{5}{|c|}{ Particular } & & & & & \multirow[t]{2}{*}{ Values } \\
\hline & Area & 1 & & & & & & & \\
\hline & Yield & 66,500 & & & & & & & \\
\hline & Selling Price & 1 & & & & & & & \\
\hline \multirow[t]{2}{*}{ I. } & REVENUE: & & & & & & & Php & $66,500.00$ \\
\hline & Value of prod & ction & & & & & & & $66,500.00$ \\
\hline \multirow[t]{18}{*}{ II. } & COSTS: & & & & & & & & \\
\hline & Direct labor & & & & & & & & \\
\hline & Harrc & wing & Php & 2,000 & & at $\mathrm{P} 2 \mathrm{C}$ & ha $(2 \mathrm{t}$ & & $4,000.00$ \\
\hline & Furro & ving & & 4 & MAD at & Php & 400 & per day & $1,600.00$ \\
\hline & Plant & & & 12 & MD at & Php & 200 & per day & $2,400.00$ \\
\hline & Fertil & zer application & & 4 & MD at & $\mathrm{Php}$ & 200 & per day & 800.00 \\
\hline & Off-b & Irring & & 4 & MAD at & Php & 400 & per day & $1,600.00$ \\
\hline & Hillir & g-up & & 4 & MAD at & Php & 400 & per day & $1,600.00$ \\
\hline & Harv & sting & & 15 & MD at & Php & 200 & per day & $3,000.00$ \\
\hline & Haul & & & 10 & MAD at & Php & 400 & per day & $4,000.00$ \\
\hline & Sub-t & & & & & & & & $19,000.00$ \\
\hline & Direct materi & & & & & & & & \\
\hline & Corn & eeds & & 3 & bags at & Php & 3500 & per bag & $10,500.00$ \\
\hline & Urea & & & 3 & bags at & Php & 1000 & per bag & $3,000.00$ \\
\hline & Com & lete & & 2 & bags at & Php & 1000 & per bag & $2,000.00$ \\
\hline & Herb & cide & & 1 & liter at & Php & 500 & per liter & 500.00 \\
\hline & Sub- 1 & & & & & & & & $16,000.00$ \\
\hline & Total direct & & & & & & & & $35,000.00$ \\
\hline \multirow[t]{3}{*}{ III. } & NET REVEN & & & & & & & & $31,500.00$ \\
\hline & Break-even 1 & ice (Php per kg) & & & & & & & 0.53 \\
\hline & Break-even & $y$ (kg per ha) & & & & & & & 35,000 \\
\hline
\end{tabular}

MAD - man animal day

*MD - man day 
Option 3 - Plant corn, process it as green silage and sell it as silage

A corn farmer who opted to plant green corn for silage, can either sell it as green corn for silage or process it as green corn silage and sell it as green corn silage. The profitability of planting green corn, processing it as silage, and selling it as silage is shown in Table 3 below.

The net revenue of Php146,565.00 per ha per cropping can be generated. Given two croppings in a year, a net revenue of Php293,130.00 is expected. If three croppings per year are feasible a net revenue of Php439,695.00 will be attained.

Table 3. Cost and return analysis of planting corn, processed as silage, and sold as silage (Option 3).

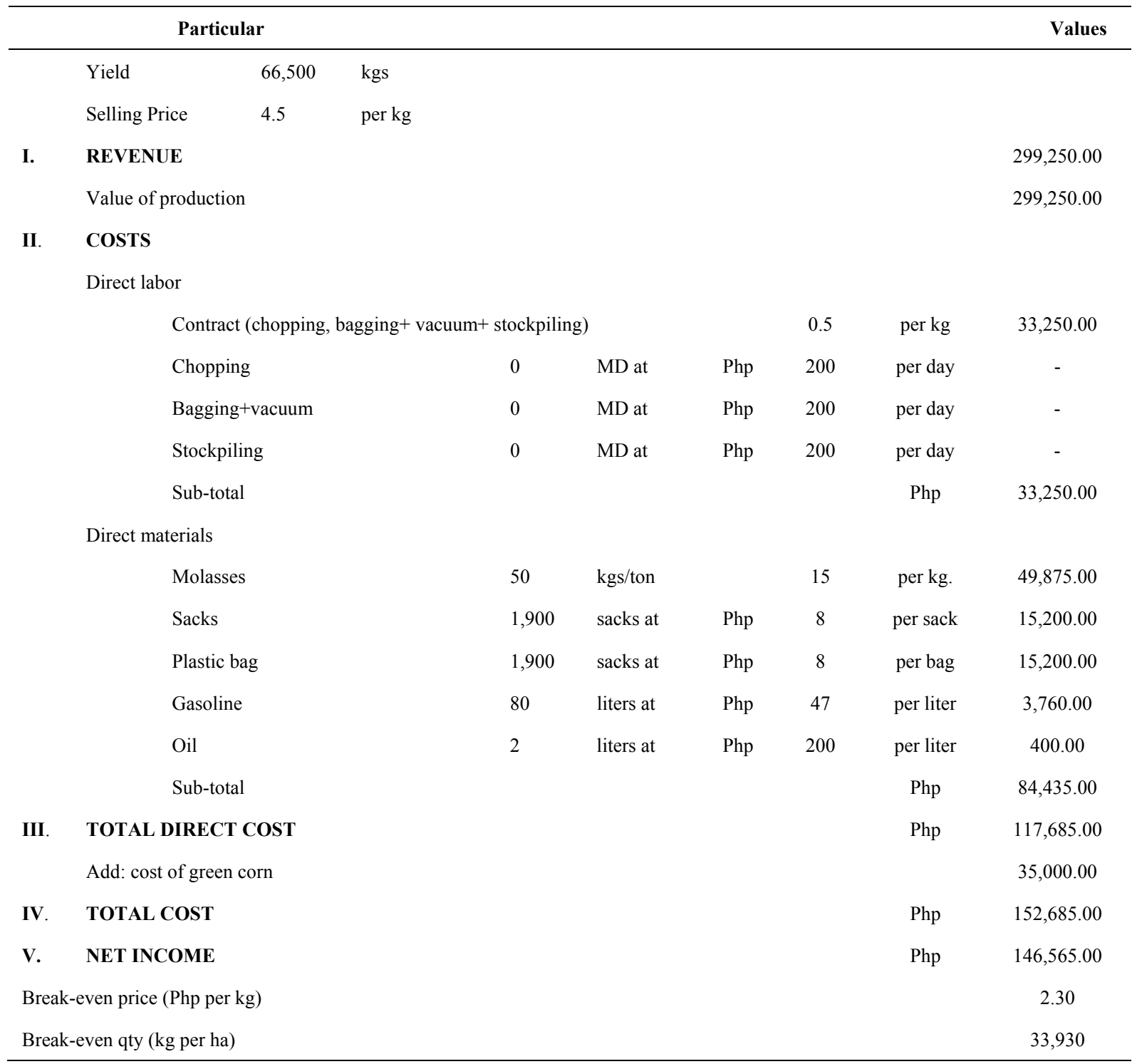


Option 4 - Plant corn, process it as green corn silage, feed it as silage to 3 heads dairy Cattle owned by the family. The revenue was be sales of milk produced.

A typical small hold dairy farmer (either owns Carabao or buffalo), based on the household survey conducted in the two partner dairy cooperatives (Malaya Development Cooperative and San Agustin Dairy Cooperative), a dairy farm family has an average farm lot of 1.5 hectares and 3 heads dairy Carabao or buffalo per farm family. A farm family therefore in addition to Option 1 to Option 3 has an added option (Option 4). The farm family can plan corn, process it as silage, and feed it to the farm family's dairy animals. The profitability analysis of this option (Option 4) is shown in Table 4.
Well-nourished dairy Carabao can produce 12 liters per day, 10 liters per day, and 6 liters per day for early lactation, mid-lactation, and late lactation respectively. Dairy Carabao for the duration of 280 days lactation per year, can produce 2680 liters. With an average farmgate price of Php50.00 per liter, an annual gross revenue of Php134,000.00 can be achieved. Lactating dairy Carabao is fed $40 \mathrm{kgs}$ green corn silage per day, given $0.5 \mathrm{~kg}$ UMMB per day, and $2 \mathrm{~kg}$ concentrate per day for the 280 days lactation period per year to be able to attain the desired milk production per day. A total cost of Php62,815.00 for the whole duration of lactation per year will be incurred. A net income of Php71,185.00 can be achieved.

Table 4. Cost and Return Analysis of dairy cattle, feeding of green corn silage+ UMMB+ concentrate (Option 4).

\begin{tabular}{|c|c|c|c|}
\hline Particular & & & Value \\
\hline REVENUE & & $\mathrm{P}$ & $134,000.00$ \\
\hline Value of milk produced & Qty & & \\
\hline 12 liters/day, early lactation (1-100 days) & 1200 & & $60,000.00$ \\
\hline liters/day, mid lactation (101-200 days) & 1000 & & $50,000.00$ \\
\hline liters/day, Late lactation (201-280 days) & 480 & & $24,000.00$ \\
\hline COST & & & $62,815.37$ \\
\hline \multicolumn{4}{|l|}{ Value of green corn silage } \\
\hline kgs Green corn silage per head/day & & & $25,715.37$ \\
\hline cost per kg green corn silage & & & \\
\hline \multicolumn{4}{|l|}{ Value of UMMB } \\
\hline kgs per head per day at $\mathrm{P} 1200 / 10 \mathrm{kgs}$ & & & $16,800.00$ \\
\hline \multicolumn{4}{|l|}{ Value of concentrate } \\
\hline $\mathrm{kgs} / \mathrm{head} /$ day at P1450/bag, 40kgs/bag & & & $20,300.00$ \\
\hline NET CASH INCOME & & & $71,184.63$ \\
\hline
\end{tabular}

Table 5. Cost and Return Analysis of dairy buffalo, feeding of green corn silage + UMMB + concentrate (Option 5)

\begin{tabular}{llll}
\hline & \multicolumn{1}{c}{ Particular } & & Value \\
\hline REVENUE & & Qty & P \\
\multicolumn{2}{l}{ Value of milk produced } & Value (P) \\
5.5 & liters/day, early lactation (1-100 days) & 550 & $44,000.00$ \\
4 & liters/day, mid lactation (101-200 days) & 400 & $32,000.00$ \\
3 & liters/day, Late lactation (201-280 days) & 240 & $19,200.00$
\end{tabular}

\section{COST}

Value of green corn silage

40 kgs Green corn silage per head/day

2.3 cost per kg green corn silage

Value of UMMB

$\underline{0.5}$ kgs per head per day at P1200/10 kgs

Value of concentrate 
Option 5 - Plant corn, process it as green corn silage, feed it as silage to 3 heads dairy buffalo owned by the family. The revenue will be sales of milk produced

Farm families with dairy Carabao (the case of SSDA of SADACO members) with farm lots suited to corn production, in addition to Option 1 -Option 3, they have an added option (Option 5). They will plant corn, process it as green corn silage, feed it as silage to 3 heads dairy buffalo owned or taken care of by the family. The revenue will be sales of milk produced. The profitability of this option is shown in Table 5.

In Option 5 (i.e. plant corn, process it as green corn silage, feed it as silage to 3 heads dairy Buffalo owned by the family), well-nourished dairy buffalo can produce 5.5 liters per day, 4 liters per day, and 3 liters per day for early lactation, mid-lactation and late lactation periods respectively. The prevailing market price of dairy buffalo if Php 80.00 per liter. For the whole 280 days lactation period per year, a total of 1,190 liters is produced. At the Php 80.00 per liter prevailing price, a gross revenue of Php95,200.00 is achieved. Green corn silage, UMMB and concentrate for the 280 days lactation period is valued Php62,815.00. A net income of Php32,385.00 was earned.

OPTION 6- Plant napier grass (pachong) and feed it ad libitum as forage to 3 heads dairy buffalo whed by the family. The revenue was the sales of milk produced.

Small hold dairy buffalo owners with farm lots (the case of farm families of MDC), Option 6 (i.e. plant Napier grass (pachong) and feed it ad libitum as forage to 3 heads dairy buffalo owned by the family was an added option. The profitability of this option as shown in Table 6 .

Table 6. Cost and Return of dairy carabao, ad libitum feeding of grasses (Option 6)

\begin{tabular}{|c|c|c|c|}
\hline \multicolumn{2}{|r|}{ Particular } & \multicolumn{2}{|r|}{ Value } \\
\hline \multicolumn{2}{|c|}{ REVENUE } & $\mathrm{P}$ & $34,000.00$ \\
\hline \multicolumn{4}{|c|}{ Value of milk produced } \\
\hline 4 & $\begin{array}{l}\text { liters/day, early lactation } \\
\text { (1-100 days) }\end{array}$ & 400 li & $20,000.00$ \\
\hline 2 & $\begin{array}{l}\text { liters/day, mid lactation } \\
\text { (101-200 days) }\end{array}$ & $200 \mathrm{li}$ & $10,000.00$ \\
\hline 1 & $\begin{array}{l}\text { liters/day, Late lactation } \\
\text { (201-280 days) }\end{array}$ & $80 \mathrm{li}$ & $4,000.00$ \\
\hline \multicolumn{4}{|c|}{ COST } \\
\hline \multicolumn{2}{|c|}{ Value of forage/ grass } & & $5,845.33$ \\
\hline 40 & $\mathrm{kgs}$ grass per day/day & & $5,845.33$ \\
\hline 0.52 & cost per kg & & \\
\hline NET & H INCOME & & P28, 155.00 \\
\hline
\end{tabular}

Forage (e.g. Napier grass plus legumes) if fed ad libitum to dairy buffalo, it can produce milk 4 liters per day, 2 liters per day, and 1 liter per day for early lactation, mid-lactation, and late lactation respectively. A total of 680 liters is produced for the 280 days lactation per year. This is worth
Php34,000.00 valued at Php50.00 per liter of dairy buffalo o milk. Forages fed for 280 days at $40 \mathrm{kgs}$ per head per day is worth Php5,845.00. For one year, a net cash income of Php28,155.00 can be earned.

Option 7 - Plant napier grass (pachong) and feed it ad libitum as forage to 3 heads dairy carabao / buffalo owned by the family. The revenue will be sales of milk produced.

To smallholder dairy carabao /buffalo owners, Option 7 (i.e. plant Napier grass (pak-chong) and feed it ad libitum as forage to 3 heads dairy buffalo owned by the family) is an option worth evaluating.

A dairy carabao /buffalo fed with forage ad libitum can produce 2 liters, 1.5 liters, 0.5 liter per day for early lactation, mid-lactation, and late lactation respectively. For whole 280 days lactation period per year, one carabao/ buffalo can produce 390 liters milk. At a farm gate price of Php80.00 per liter, a gross revenue of Php31,200.00 can be earned. Deducting cost of forage, a net cash income of Php25,355.00 was earned. The details are shown in Table 7.

\section{Comparative Costs and Returns of Options 1 to 7}

Option 1 vs. Option 2. At current prices, planting corn selling it as grain and at the assumed yield per ha of 120 cavan's (50 kgs/cavan), a positive net income of Php19,000 per cropping is achievable or Php38,000.00 per ha per annum (Option 1). If there is market for green corn for silage, the traditional corn farmer has an added selling option, i.e. plant corn, harvest and sell it as green corn for silage (Option 2). The decision depends on which option gives the highest profit per annum.

Table 7. Cost and Return Analysis of dairy carabao /buffalo, ad libitum feeding of grasses (napier,etc) (Option 7).

\begin{tabular}{|c|c|c|c|c|}
\hline \multicolumn{3}{|c|}{ Particular } & \multicolumn{2}{|r|}{ Value } \\
\hline \multicolumn{2}{|c|}{ REVENUE } & & $\mathrm{P}$ & $31,200.00$ \\
\hline \multicolumn{2}{|c|}{ Value of milk produced } & Qty & & Value (P) \\
\hline 2 & $\begin{array}{l}\text { liters/day, early lactation } \\
\text { (1-100 days) }\end{array}$ & 200 & & $16,000.00$ \\
\hline 1.5 & $\begin{array}{l}\text { liters/day, mid lactation } \\
\text { (101-200 days) }\end{array}$ & 150 & & $12,000.00$ \\
\hline 0.5 & $\begin{array}{l}\text { liters/day, Late lactation } \\
\text { (201-280 days) }\end{array}$ & 40 & & $3,200.00$ \\
\hline \multicolumn{2}{|c|}{ COST } & & & $5,845.33$ \\
\hline \multicolumn{3}{|c|}{ Value of forage/ grass } & & $5,845.33$ \\
\hline 40 & kgs grass per day/day & & & $5,845.33$ \\
\hline 0.52 & cost per kg & & & \\
\hline \multicolumn{3}{|c|}{ NET CASH INCOME } & & P $25,354.67$ \\
\hline
\end{tabular}

On a per cropping, net profit per ha for Option 2 was Php31,500.00 which was $40 \%$ higher than Option 1 (Php19,000.00). A rational corn farmer can choose Option 2.

On a per annum basis, the more a corn farmer will 
choose planting corn and sell it as green corn for silage (see Table 8 for details). Among the reasons why Option 2 is superior to Option 1 are the following:

i. Green corn was harvested 65-85 days after planting which is earlier than corn crop sold as grain. The risk of typhoon or drought was lower.

ii. If irrigation facility is available, 3-4 cropping's per year is possible. Added income was higher.

iii. The value of green corn for silage was higher than corn sold as grain.

Option 2 vs. Option 3. Selling green corn for silage (Option 2) can give a net income of Php31,500.00 per cropping. If the farmer processed his crop as green corn silage (Option 3), the corn farmer realized a net income of Php146,565.00 per cropping. The net income for Option 3 was 4.7 times the net income for Option 2. Processing corn crop as green corn silage was superior to Option 2 (Table 8).

Option 4 vs. Option 6. A dairy cattle farmer has two options, feed his dairy carabao with green corn silage+UMMB+ concentrate (Option 4) or continue with his traditional practice of feeding forage but ad libitum (Option 6). Option 4 is superior to Option 6. Net income was almost doubled because of increased milk produced per head per day (Table 8).

Option 5 vs. Option 7. Among smallholder dairy buffalo owners, feeding their dairy buffalo with green corn silage + $\mathrm{UMMB}+$ concentrate (Option 5) is superior to Option 7 (feeding forage ad libitum). Option 5 has a net income of Php32,385.00 per head per year of dairy buffalo compared with Php25,355.00 income from Option 7 (Table 8 for details).

In summary, smallholder farmers can have positive net income from all the different options, but to go in Option 3 (Plant corn, process it and sell it as silage), they can have greater opportunity of net profit of around Php146,565.00 annually for dairy farmers who want to engage in this activity. From other similar dairy farmer's engagement, this has around 7.71 times higher of net profit than can be obtained in option 1 and 4.65 times higher of net profit than can obtained in Option 2. To those farmers with dairy animals, Option 5 (Dairy Carabao/ Bufallo, feeding of green corn silage $+\mathrm{UMMB}+$ concentrate) have better net profit of Php71,184.63 from the sales of milk alone not to mention other benefits that can be derived from this option such as animal stocks, off-springs, and manure that can increase further the net income of the farmer. This has an advantage of net income of 2.53 times from option 4; 2.8 times from option 6; and 2.2 times in option 7. Similarly, it will be advantageous to dairy buffalo raisers to feed their dairy buffalo with green corn silage + UMMB + concentrate (Option 5). The benefits are as stated above.

Table 8. Summary of Cost and Return Analysis of the Different Options

\begin{tabular}{cccccccc}
\hline Particular & Option 1 & Option 2 & Option 3 & Option 4 & Option 5 & Option 6 & Option 7 \\
\hline Revenue & $48,000.00$ & $66,500.00$ & 299,250 & $134,000.00$ & $95,200.00$ & $34,000.00$ & $31,200.00$ \\
Cost & $29,000.00$ & $35,000.00$ & 152,685 & $62,815.37$ & $62,815.37$ & $5,845.33$ & $5,845.33$ \\
Net Revenue & $19,000.00$ & $31,500.00$ & 146,565 & $71,184.63$ & $32,384.63$ & $28,154.67$ & $25,354.67$ \\
\hline
\end{tabular}

OPTION 1 - plant corn and sell it as grain (as usual practice)

OPTION 2 - plant corn and sell it as green corn for silage

OPTION 3 - Plant corn, process it and sell it as silage

OPTION 4 - Plant corn, process it as green corn silage, feed it as silage to 3 heads dairy cattle owned by the family. The revenue will be sales of milk produced.

OPTION 5- Plant corn, process it as green corn silage, feed it as silage to 3 heads dairy buffalo owned by the family. The revenue will be sales of milk produced.

OPTION 6 - Plant napier grass (pachong) and feed it ad libitum as forage to 3 heads dairy animals owned by the family. The revenue will be sales of milk produced.

OPTION 7 - Plant napier grass (pachong) and feed it ad libitum as forage to 3 heads dairy buffalo owned by the family. The revenue will be sales of milk produced. 


\section{Enterprise Viability Analysis}

\section{A. Silage Commercialization}

The corn green silage production is one of the promising industries in the Cagayan Valley region specifically in the province of Isabela where vast corn production is located. Considering a high demand of silage in dairy and feedlot producing provinces like Batangas, Bulacan, Pangasinan etc. This can be an alternative livelihood of the dairy farmers in the locality where they can engage production on it. An estimate of 2 million metric tons a month for the aggregate domestic demand of corn silage from the said locations. Aside from that, there is a huge demand for corn silage in international markets like Korea and Japan. The farmers have options to engage in green corn silage production: either they engage in planting corn ensile it and sell; buy a standing crop for silage; and plant corn and sell it as standing crops to the individuals who engage in silage production. There are existing consolidators who are engaged in transporting and selling the product in the market which the farmers can also sell their produced silage to them if they cannot bring their product to the end-users due to lack of transport facility.[8],[13].

\section{Option 1 - Plant corn, ensile it and sell it as silage}

Amount column 1 of Table 9 and Annex 1 shows the projected income and analysis of farmers engaged in green corn production and silaging for 1.5-hectare average corn area in each for both farmer organizations (SADACO and MDC). The green corn fit for silage production is an age ranging from 65 to 80 days where the crop has already bearing milky grain fruits which contribute to high protein content silage.[2], [4]. The farmers can have a minimum of 3 cropping's a year or if they have equipped with an irrigation system, they can have up to 4 cropping's a year.

If the farmer intense to go option 1 , he/she can have a total capital investment of around Php275,000.00 for corn green production and silage making operation. Greater portion of the budget can be used to acquire the equipment (Php226,000.00) for silage production. The capital can be acquired from the bank at an interest of $18 \%$ per annum for 5 years to pay. They can be negotiated to the Land Bank of Philippines or from one of the Department of Agriculture loan windows. Based on the five-year study, the dairy farmers can have an average profit margin of $\mathrm{Php}$ 666,225.00 annually (4.5 area-cropping's a year) then less the average operating cost of Php546, 268.91. They can have an average net operating profit of Php119,956.09. As shown in the economic analysis for option 1, the farmers can have a return on investment (ROI) of $43.62 \%$, payback period of 2.52 years; benefit-cost ratio (BCR) @ 12\% of 1.05; net present value (NPV) @ 12\% of Php150,152.03; and an internal rate of return (IRR) of $31.10 \%$ which are favorable.

The ROI implied that for every peso investment, there can be 44 centavos return which were higher to the opportunity cost of capital of 12 percent per annum. The payback period suggested that the farmers who adopted this scheme can sustain their operation after 2.52 years. This means that the operation can be financed by its generated income throughout five years of operation. On the benefit-cost ratio analysis of 1.05 suggested that the discounted benefit of the project was greater than to the discounted cost of inflows. The NPV of Php150,152.03 suggested also that the project can have that amount as a net benefit after five years of operation. The IRR of $31.10 \%$ indicated that the project can generate around 31 centavos for every one (1) peso investment which was higher to the opportunity cost of capital of $12 \%$ per annum.

\section{Option 2 - Make business with silage making and sell}

If the dairy farmers selected the second option to go into silage production by buying the standing crop (second amount column of Table 9 and Annex 2), he/she could realize the average profit margin of Php978,075.00 and an average cost of operation for silage making of Php860,143.91 for 1.5 hectare standing corn crop at 3 cropping's a year. He can obtain an average operating profit of Php1 17,931.00. This operation can realize an ROI of $42.88 \%$, a payback period of 2.6 years, benefit-cost ratio (BCR)@12\% of 1.06, net present value (NPV)@12\% of Php142,852.35 and internal rate of return (IRR) of $30.22 \%$. The economic indicators which have mentioned were favorable.

\section{Option 3 - Plant corn and sell it standing crop}

For option number 3 (third amount column of Table 9 and Annex 3), the dairy farmers can engage in corn production and sell it as standing crops to the independent silage producer, he can have a gross sale of Php354,375.00 for his 1.5 -hectare cornfield at 3 cropping's annually with an estimated average total cost of production of Php191,563.91. In this scheme, the dairy farmers can have an alternative average net operating profit of Php162,811.09. It has better economic results of ROI of $135.68 \%$, a payback period of 0.82 years, benefit-cost ratio (a) $12 \%$ of 1.38 , net present value (a) 12\% of Php459,634.71 and an internal rate of return of 124.21\%. These were all favorable economic measures for business operation.

All the options offered to the dairy farmers in business for commercialization were all recommended. If the dairy farmers have no capital to use in acquiring the processing equipment for silage production, option 3 was recommended because it has better economic results as compared to the two options ( 1 and 2). However, at the end of the fifth year of operation, no equipment was acquired. The first and second options were recommended to those dairy farmers capable of investing capital to acquire assets for processing of silage. The second option business operator has more advantage of their capital investment 
since they have a short business engagement which results in a fast cycle of capital as compared to options 1 and 3.

\section{B. Dairy Milk Production}

\section{Option 4 - Carabao/Buffalo Production fed with Green Corn Silage}

The dairy carabao fed with corn silage has increased significantly their milk production for $42 \%$ from the average production of 5 liters per head during the peak period in the case of MDCI at Malaya, Mallig, Isabela with an average of 3 heads of animals by the members of the cooperative. Based from the data gathered as shown at amount column 4 of Table 9 and Annex 4, they realized a profit margin Php353,646.00 from the sales of milk and an average of the total production cost of Php185,733.90 annually with an average net operating profit of Php167,912.10 annually.

The data in carabao dairy production of the MDC farmers showed economically favorable. For the average initial investment of Php287,500.00 for three (3) heads carabao dairy production with an ROI of $58.40 \%$. It was computed to recover back for 2.03 years based from their current sales of the volume of milk. The rest of economic measures like BCR@12\% with 1.90 ratios, NPV@12\% with Php317,785.54 and the IRR of 50.95\% were favorable. The ROI and IRR were above the hurdle rate of the opportunity cost of $12 \%$ per annum.

\section{Option 5 - Carabao/Buffalo Production fed with Green Corn Silage}

For dairy buffalo in the case of SADACO where the Dairy Association of Sinaoangan, Agustin, Isabela as the conduit of the project, they engaged in the feeding of corn silage to their test animals (amount column 5 of Table 9 and Annex 5). An average of 3 heads dairy buffalo per member feeding with green corn silage to their animals, has increased their milk production by $27 \%$. It showed in table 24 , the dairy farmers incurred an average operating profit of Php337, 784.00 and an average total operating cost of Php181,470.90 with an average operating profit of Php156,425.10 per year.

On economic analysis, similar results were realized on dairy carabao production where the payback period has short recovery for an initial investment of Php287,500.00 for 3 heads dairy buffalo production. In this case, the payback period was 2.21 years. Moreover, other important economic measures were also favorable. The ROI was $54.41 \%$, BCR@12\% was 1.86, and NPV@12\% was Php276,377.48 and IRR of $46.29 \%$. The ROI and IRR were above the opportunity cost of capital of $12 \%$ per annum.

\section{Option 6 - Dairy Carabao/Buffalo ad libitum fed with grasses (Napier, etc.)}

The dairy carabao fed ad libitum with grasses (Napier, etc) in the case of MDC at Malaya, Mallig, Isabela. For an average of 3 heads dairy animals per member of the cooperative, they realized a profit margin of Php102,000.00 from the sales of milk and an average of the total production cost of Php17,535.99 with an average net operating profit of Php84,464.01 annually (column 6 of Table 9 and Annex 6).

The data in carabao dairy production of the MDC farmers showed economically favorable. For the average initial investment of Php287, 500.00 for three (3) heads carabao dairy production, with an ROI of $29.38 \%$, to recover back for 4.65 years based on sales of the volume of milk. The rest of the economic measures like BCR@12\% with 5.82 ratios, NPV@12\% with Php16, 973.85 and the IRR of $14.36 \%$ were favorable. The ROI and IRR were above the hurdle rate of the opportunity cost of $12 \%$ per annum. This option was the least viable from among the different options of the dairy farmers.

\section{Option 7 - Dairy Buffalo ad libitum fed with grasses (Napier, etc.)}

The dairy buffalo of SSDA of SADACO, Agustin, Isabela were fed ad libitum with grasses with 3 heads of dairy buffalo realized an average net operating profit of Php93,600.00 and an average total operating cost of Php17,535.99 annually. They have obtained an average net operating profit of Php76, 064.01 per year which was the least as compared with other options (column 7 of Table 9 and Annex 7).

On economic analysis, the payback period was greater than 5 years to recover the initial investment of Php287, 500.00 for 3 heads dairy buffalo production. The ROI was 26.46\%, BCR@12\% was 5.34, and NPV@12\% was negative Php13, 306.27 and IRR of $10.11 \%$. This option was not viable to engage. 
Table 9. Summary of financial and economic Information

\begin{tabular}{c|c|c|c|c|c|c|c}
\hline Particular & Option & Option & Option & Option & Option & Option & Option \\
& $\mathbf{1}$ & $\mathbf{2}$ & $\mathbf{3}$ & $\mathbf{4}$ & $\mathbf{5}$ & $\mathbf{6}$ & $\mathbf{7}$ \\
\hline Ave. margin of Profit & $666,225.00$ & $978,075.00$ & $354,375.00$ & $353,646.00$ & $337,896.00$ & $102,000.00$ & $93,600.00$ \\
Ave. Cost of Production & $546,268.91$ & $860,143.91$ & $191,563.91$ & $185,733.90$ & $181,470.90$ & $17,535.99$ & $17,535.99$ \\
Ave. Net Operating Profit & $119,956.09$ & $117,931.09$ & $162,811.09$ & $167,912.10$ & $156,425.10$ & $84,464.01$ & $76,064.01$ \\
Return on Investment (ROI) & $43.62 \%$ & $42.88 \%$ & $135.68 \%$ & $58.40 \%$ & $54.41 \%$ & $29.38 \%$ & $26.46 \%$ \\
Payback Period (Years) & 2.52 & 2.6 & 0.82 & 2.03 & 2.21 & 4.65 & $>5$ \\
Benefit-Cost Ratio & 1.05 & 1.06 & 1.38 & 1.9 & 1.86 & 5.82 & 5.34 \\
Net Present Value (Php) & $150,152.03$ & $142,852.35$ & $459,634.71$ & $317,785.54$ & $276,377.48$ & $16,973.85$ & $-13,306.27$ \\
Internal Rate of Return & $31.10 \%$ & $30.22 \%$ & $124.21 \%$ & $50.95 \%$ & $46.29 \%$ & $14.36 \%$ & $10.11 \%$ \\
\hline
\end{tabular}

Note: Option 1 - Plant corn and make it silage and sell

Option 2 - Make business with silage making and sell

Option 3 - Plant corn and sell it standing crop

Option 4- Dairy carabao - fed with corn silage

Option 5 - Dairy Buffalo- fed with corn silage

Option 6 - Dairy carabao ad libitum fed with grasses (Napier, etc)

Option 7 - Dairy Bufallo ad libitum fed with grasses (Napeir, etc)

\section{Summary/ Conclusion}

Profitability and viability assessment is important to know whether your business is gaining and losing. This study assessed the profitability and viability for the commercialization of green corn-based silage production for dairy in Cagayan Valley. Specifically, it aimed to: a.) determine the cost and return analysis of producing corn green silage; b.) compare the cost and return for the different opportunities of dairy farmers in engaging silage production; and c.) assess the profitability and viability of dairy as fed with green corn silage.

The data were gathered from Malaya Development Cooperative (MDC) at Mallig, and San Agustin Dairy Cooperative (SADACO) at San Agustin, Isabela in 2017 2019. MDC has operated in Dairy carabao/buffalo while SADACO in dairy Carabao. There were various packages of technologies introduced for adoption like a) production green corn for silage, and b) green corn silage. There were various options for green corn such as: 1) plant corn and sell it as grain (as usual practice), 2) plant corn and sell it as green corn for silage, and 3) plant corn, process it as green silage and sell it as silage, 4) Plant corn, process it as green corn silage, feed it as silage to 3 heads dairy Cattle owned by the family, 5) Plant corn, process it as green corn silage, feed it as silage to 3 heads dairy buffalo owned by the family, 6) Plant napier grass (pachong) and feed it ad libitum as forage to 3 heads dairy Cattle owned by the family, and 7) Plant napier grass (pachong) and feed it ad libitum as forage to 3 heads dairy buffalo owned by the family with corresponding net income of Php19,000; Php31,500; Php145,565.00; Php71,184.63; Php32,384.63; Php28,154.67; Php6,25,354.67, respectively. Comparing options 1 to 3 , option 3 has obtained with the highest net

income, while comparing options 4 to 7 , option 4 has obtained with the highest net income.

For viability assessment, option 3 has the lowest payback period of 0.82 year which is very favorable from among the options. On the benefit-cost ratio, option 6 has the highest ratio of 5.82 which is called very favorable as compared to other options. In terms of net present value, option 3 with Php459,634.71 is the best, while the worst option is 7 with Php-13,306.27. As to the internal rate of return, option 3 has obtained with the highest IRR of $124.21 \%$ which considered very favorable as compared to other options.

Based on the result, green corn silage was very effective to the dairy animals both cattle and buffalo to increase milk production. It also provided options to the dairy farmers to engage business selling green corn silage to other dairy producers not only in the province but also to other regions where feed resources are scarce. Green corn silage has huge demand waiting in the meat and dairy production provinces like Batangas, Bulacan, Laguna and Pangasinan not mention the demand by foreign markets. There was greater income that the dairy farmers can generate and augment and increase their sources of income. It has greater return on investment and only few years to recover the investment. It was a viable project with good net present value of projected inflows and an internal rate of return above the hurdle rate of $12 \%$ per annum.

\section{REFERENCES}

[1] Boehlie, Michael. "Business Challenges in Commercialization of Agricultural Technology. 
International Food and Agribusiness Management Review ".Volume 7, Issue 1, 2004.

[2] Ferraretto, L.F., Shaver, R.D., and Luck, B.D. Silage review: Recent advances and future technologies for whole-plant and fractionated corn silage harvesting. J. Dairy Sci. 101:39373951, 2016.

[3] Furoc, R.E. and E.Q. Javier. Integration of fodder production with intensive cropping's involving rice: I. Grass production from irrigated lowland rice field. II. Herbage weeds during juvenile stage of the rice crops. In: State of the Art Bibliography of Forage, Pasture and Grasslands Researches. PCARRD Livestock Bibliography Series No. V 1983

[4] Gebremedhin, B, Ahmed, M.M, and S.K. EHUI, S. K. "Determinants of adoption of Improved forage technologies in crop-livestock mixed systems: evidence from the highlands of Ethiopia. In Tropical Grasslands”, Volume 37, 262-273. 2003

[5] Marbella, J.L., Pineda, C.I., Bulay, R.N., Castillo A.C. and Moog, F.A. Utilization of rice straw and ipil-ipil in cattle fattening at Magalang, Pampanga. Phil. J. Anim. Ind. Vol 36 (14): 81-87. 1981

[6] Sevilla, C.C., C.B. Perez, Jr. and O.M. Gatmaitan. The effect of ipil-ipil (Leucaenaleucocephala) leaves in rice based rations on growth performance and carcass characteristics and yields of bulls. In: State of the Art Bibliography of Beef/Chevon Researches. PCARRD Livestock Bibliography Series No. 3/ 1983 Unpublished

[7] Amhara National Regional State. Bahir Dar, Ethiopia. (Unpublished)

Website

[8] Bureau of Agriculture and Rural Development. Animal
Feeding Strategy. http://www.thecattlesite.com/articles/2797 /production-of-urea-molasses-mineral-blocks/. 2010

[9] Food and Fertilizer Tevhnology Center. Indigenous Feed Resources for Asian Livestock. http://www. fftc.agnet.org/ library.php? func $=$ view \&style $=$ type $\& i d=20110729141254$, 2019

Books

[10] Philippine Society of Animal Nutritionists. PHILSAN, Feed Reference Standards, $4^{\text {th }}$ Edition Copyright 2010, pp 159-177. 2010

[11] Right Agri-Development, Inc. 108 Road 2 corner Road 5 CRS Building, Unit 303 3rd floor, Bagong Pag-asa, Quezon City, Feb. 2016.

\section{Conference Paper}

[12] Acasio, R.N. and Victorio-Espaldon, E. "Feeding systems of carabaos (swamp buffaloes) in smallhold rice-based farming village in Northern Luzon, Philippines. Paper presented at Workshop on the Utilization of Straw in Ruminant Production, 1991.

[13] Aquino, D. L. Forage Conservation and Enrichment. Paper presented during the 16th DAIRY CONGRESS AND EXPO, Bacolod Pavilion Hotel, Bacolod City, February 7-9, 2013.

[14] International Livestock Research Institute. Asian livestock: challenges, opportunities and the response. In Proceedings of an international policy forum held in Bangkok, Thailand, 16-17 August 2012.

[15] Tengco, PL. and V.R. Carangal. Increasing food production and animal feed through integration of forage legumes in rice-based farming systems. Paper presented during the 28th PSAS Annual Convention, PICC, Metro Manila, Philippines. Nov. 21-22. 1991 